\title{
PENGELOLAAN KAS KECIL PADA PT BADAR JAYA SAKTI PONDOK AREN TANGERANG SELATAN
}

\section{Nurwinda Safitri}

Universitas Pembangunan Jaya Tangerang Selatan, Indonesia

Email: nsafitri0910@gmail.com

\begin{abstract}
Abstrak
Agar dapat bersaing, perusahaan harus mampu mengelola dana perusahaan sesuai dengan rencana yang telah ditentukan untuk membantu manajer dalam mengambil keputusan yang tepat. Contoh pengelolaan dana perusahaan adalah penggunaan dana kas kecil, oleh karena itu perusahaan harus mengelola kas kecil dengan baik. Jika tidak ada pengelolaan harian dalam jumlah kecil, maka dapat mengganggu kelancaran operasional bisnis. Metode penelitian yang digunakan dalam penelitian ini adalah deskriptif kuantitatif dengan metode wawancara yaitu melakukan tanya jawab secara langsung dengan mengajukan pertanyaan yang berkaitan dengan kas kecil, wawancara dilakukan dengan Bapak Akbar selaku bagian Admin pada PT Badar Jaya Sakti (BJS). Studi dokumentasi yaitu mengumpulkan data tambahan dengan melampirkan dokumen-dokumen terkait kas kecil yang dilakukan oleh PT BJS. Periode data yang digunakan adalah Juni 2021 - Agustus 2021. Pengelolaan kas kecil yang diterapkan oleh PT BJS yaitu dengan menggunakan metode berubah-ubah (Fluctuation System). Dimana saldo rekening kas kecil tidak tetap, tetapi berfluktuasi tergantung pada jumlah pengisian dan jumlah dari kas kecil. Berdasarkan permasalahan yang terjadi pada PT BJS khususnya pada standar operasional prosedur kas kecil sering terjadi kesalahan berupa pencatatan yang tidak akurat pada buku kas dan terdapat beberapa metode yang tidak sesuai dengan standar operasional prosedur. Prosedur transaksi keuangan kas kecil, membantu menghindari penipuan yang mungkin dilakukan oleh pihak-pihak yang terlibat.
\end{abstract}

Kata Kunci: kas kecil; pengelolaan kas kecil; metode kas kecil

\section{Abstract}

In order to compete, companies must be able to manage company funds according to a predetermined plan to assist managers in making the right decisions. An example of managing company funds is the use of petty cash funds, therefore companies must manage petty cash properly. If there is no daily management in small amounts, it can disrupt the smooth operation of the business. The research method used in this research is descriptive quantitative interview method, namely conducting direct question and answer by asking questions related to petty cash, interviews were conducted with Mr. Akbar as the Admin section at PT Badar Jaya Sakti (BJS). Documentation study is collecting additional data by attaching documents related to petty cash conducted by PT BJS. The data period used is June 2021 - August 2021. Petty cash management implemented by PT BJS is by using the fluctuating method (Fluctuation System). Where the petty cash account balance is

\begin{tabular}{ll}
\hline How to cite: & Safitri, N., (2021) Pengelolaan Kas Kecil Pada PT Badar Jaya Sakti Pondok Aren Tangerang \\
& Selatan, Syntax Idea, 3(12), https://doi.org/10.36418/syntax-idea.v3i12.1616 \\
E-ISSN: & 2684-883X \\
Published by: & Ridwan Institute
\end{tabular}


not fixed, but fluctuates depending on the amount of filling and the amount of petty cash. Based on the problems that occurred at PT BJS, especially in the standard operating procedure for petty cash, errors often occurred in the form of inaccurate recording in the cash book and there were several methods that were not in accordance with standard operating procedures. Petty cash financial transaction procedures, help to avoid possible fraud by the parties involved.

Keywords: petty cash; petty cash management; petty cash method

Received: 2021-11-22; Accepted: 2021-12-05; Published: 2021-12-20

\section{Pendahuluan}

Kerja profesi (KP) merupakan kegiatan yang dapat memberikan gambaran yang lebih baik kepada mahasiswa tentang dunia kerja dan kesempatan untuk menerapkan teori yang dipelajari. Program Kerja Profesi memberikan kesempatan kepada mahasiswa untuk memahami, mendefinisikan, dan menerapkan analisis dalam dunia kerja (Elfin, 2021).

Kerja Profesi (KP) merupakan salah satu syarat kelulusan dengan bobot tiga (3) sks. Selain itu, KP dilakukan selama 400-440 jam atau sekitar 50-55 hari kerja, dengan maksimal delapan (8) jam kerja per hari (tanpa memperhitungkan jam istirahat di instansi/perusahaan tersebut).

Universitas Pembangunan Jaya (UPJ) mensyaratkan bahwa KP akan berlangsung setidaknya selama dua bulan, dengan beberapa pertimbangan agar mahasiswa dapat membiasakan diri dengan dunia kerja, mendapatkan pengalaman, mengerjakan pekerjaan secara keseluruhan, melakukan observasi dan mengumpulkan data untuk skripsi/tugas akhir (Aslichati, Tutisiana, Suryanto, \& Andriyansah, 2020).

Namun, di masa pandemi Covid-19 pelaksanaan KP kali ini tidak bisa berlangsung seperti biasanya. Karena kondisi tersebut, mahasiswa tidak diperbolehkan melakukan magang atau penempatan kerja di perusahaan. Oleh karena itu, selama masa pandemi Covid-19 program studi Akuntansi menyelenggarakan kegiatan KP alternatif dengan pilihan sebagai berikut: (1.) Menulis karya ilmiah melalui pendekatan studi pustaka, survei, observasi dan lain-lain tentang topik yang relevan di bidang akuntansi, yang bertujuan untuk memberikan kontribusi praktis dan teoritis untuk ilmu pengetahuan. Permasalahan yang diangkat akan diprioritaskan dengan memberikan solusi terhadap permasalahan nyata yang muncul di masyarakat. Target luaran minimal submit prosiding atau jurnal. (2.) Membuat produk alat/sarana/alat peraga untuk praktik akuntansi yang outputnya dapat dicatatkan sebagai HKI (Siregar, 2020).

\section{Metode Penelitian}

Tujuan dari penelitian ini adalah untuk menganalisis implementasi pencatatan kas kecil dan untuk mengidentifikasi metode yang digunakan dalam pembukuan kas kecil serta prosedur pencatatan petty cash pada PT Badar Jaya Sakti (BJS) Cargo Express. 
Metode penelitian yang digunakan dalam penelitian ini adalah deskriptif kuantitatif dengan metode wawancara yaitu melakukan tanya jawab secara langsung dengan mengajukan pertanyaan yang berkaitan dengan kas kecil, wawancara dilakukan dengan Bapak Akbar selaku bagian Admin pada PT BJS. Studi dokumentasi yaitu mengumpulkan data tambahan dengan melampirkan dokumen-dokumen terkait kas kecil yang dilakukan oleh PT BJS. Periode data yang digunakan adalah Juni 2021 Agustus 2021 (Akbar, Ma'ani, \& Irsyadunnas, 2019).

\section{Hasil dan Pembahasan}

\section{Metode Pengelolaan Kas Kecil pada PT BJS}

Pengelolaan kas kecil yang diterapkan oleh PT.Badar Jaya Sakti (PT BJS) yaitu dengan menggunakan metode berubah-ubah (Fluctuation System). Dimana saldo rekening kas kecil tidak tetap, tetapi berfluktuasi tergantung pada jumlah pengisian dan jumlah dari kas kecil.

PT BJS tidak menetapkan angka pasti untuk pengisian kembali dana kas kecil dalam satu periode pengeluaran. Dana kas kecil tersebut digunakan untuk membiayai kegiatan-kegiatan operasional perusahaan yang jumlahnya relatif kecil dan bersifat rutin. Pengisian kembali dana kas kecil pada PT BJS dilakukan setiap akhir periode (setengah bulan) atau saat habis (Nariswari \& Subkhan, 2018).

Dengan metode ini, jumlah pengisian kembali kas kecil tidak harus sama dengan saldo awal, bisa kurang atau lebih. Pencatatan kas kecil dengan metode ini harus dicatat dalam jurnal dengan mencatat debit biaya dan kredit pengeluran. Pada dasarnya, jumlah kas kecil yang ada disesuaikan dengan kebutuhan pengguna (Fitriani, 2021).

Dalam metode berubah-ubah (Fluctuation System), pengadaan dana kas kecil dilakukan dengan beberapa prosedur sebagai berikut berikut (Saleh, 2018):

1. Pembentukan awal saldo kas kecil dicatat dengan mendebit rekening kas kecil.

2. Pengeluaran kas kecil dicatat dengan mengkredit rekening kas kecil, sehingga setiap saldo rekening ini berfluktuasi.

3. Pengisian kembali kas kecil dilakukan dengan jumlah yang diperlukan dan didebet dari rekening kas kecil. Dalam sistem ini, saldo rekening berfluktuasi dari waktu ke waktu.

\section{Pembentukan Dana kas kecil}

Tujuan pengadaan kas kecil adalah untuk (Wati \& Kusumo, 2016):

1. Mengatasi masalah perlengkapan dan atau persediaan kantor yang dialami oleh divisi-divisi kantor.

2. Menghindari pembayaran yang tidak ekonomis juga tidak praktis untuk biaya yang relatif kecil dan mendadak.

3. Meringankan beban staff karyawan dengan memberikan pelayanan yang maksimal kepada pelanggan, termasuk penanggung jawab hubungan bisnis.

Manajemen PT BJS membuat rencana anggaran perusahaan, salah satunya dengan membentuk dana kas kecil dan menetapkan setiap tanggal 01 dilakukan 
pembentukan dana awal kas kecil sebesar Rp.10.000.000,-. Kas kecil dalam bentuk uang atau cek dengan sejumlah tertentu dan admin kas kecil akan mencatat kas kecil pada rekening debit dan rekening kredit adalah kas atau bank.

Tabel 1

Pembentukan Dana Kas Kecil Periode 01 Juni 2021

\begin{tabular}{lccc}
\hline \multicolumn{1}{l}{ Tanggal } & Keterangan & Debet & Kredit \\
\hline Juni 1 & $\begin{array}{c}\text { Kas Kecil } \\
\text { Kas / Bank }\end{array}$ & $10,000,000$ & \\
& Sumber: Data Perusahach & & $10,000,000$ \\
\hline
\end{tabular}

Sumber: Data Perusahaan (Data diolah)

\section{Pemakaian Dana Kas Kecil}

Pada metode fluktuasi, transaksi-transaksi yang terjadi langsung dicatat pada buku pengeluaran kas kecil yang berfungsi sebagai jurnal dengan mengkredit rekening kas kecil dan mendebet beban transaksi.

Tabel 2

Pemakaian Dana Kas Kecil Periode 01-02 Juni 2021

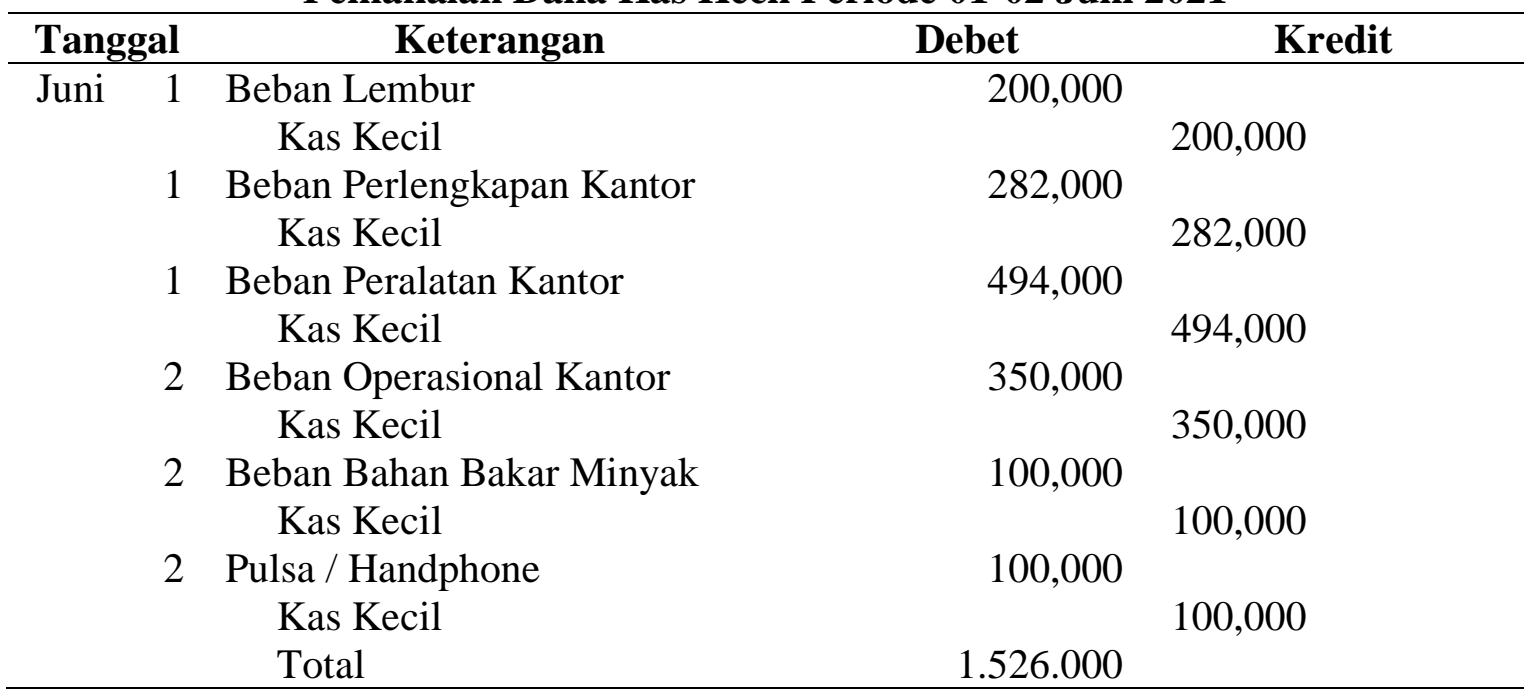

Sumber: Data Perusahaan (Data diolah)

\section{Pengisian Kembali Dana Kas Kecil}

Pada metode fluktuatif, saat pengisian kembali dana kas kecil terserah kepada admin kas kecil akan mengisi atau menambah jumlah dana kas kecilnya. Jadi ketika admin kas kecil meminta pengisian pada tanggal 03 Juni 2021 sebesar Rp. 15.000.000,- maka saldo dana kas kecil akan menjadi Rp. 23.474.000,-. Saldo ini berbeda dengan saat pembentukan dana kas kecil sebesar Rp. 10.000.000,-- 
Tabel 3

Pengisian Kembali Dana Kas Kecil Periode 03 Juni 2021

\begin{tabular}{|c|c|c|c|}
\hline Tanggal & Keterangan & Debet & Kredit \\
\hline Juni 3 & Kas Kecil & $15,000,000$ & \\
\hline & Kas / Bank & & $15,000,000$ \\
\hline
\end{tabular}

Jika dalam satu periode berjalan ada kelebihan saldo kas kecil di periode akhir, maka kelebihan tersebut dikembalikan ke kas besar.

Tabel 3

Pengembalian Kas Kecil ke Kas Besar

\begin{tabular}{|c|c|c|c|}
\hline Tanggal & Keterangan & Debet & Kredit \\
\hline Juni 30 & $\begin{array}{l}\text { Kas / Bank } \\
\text { Kas Kecil }\end{array}$ & Rp. $x x x x x x x x$ & Rp. $x x x x x x x x$ \\
\hline
\end{tabular}

Sumber: Data Perusahaan (Data diolah)

\section{Prosedur Pencatatan Kas Kecil pada PT BJS}

Prosedur yaitu serangkaian kegiatan kantor yang biasanya melibatkan beberapa orang dalam satu atau lebih departemen, yang bertanggung jawab untuk memastikan keseragaman pemrosesan transaksi bisnis yang terjadi berulang kali. Urutan operasi kantor yang dilakukan untuk mencatat informasi ke dalam formulir, buku jurnal dan buku besar meliputi: menulis, menggandakan, menghitung, mengkode, menyimpan, memilih (mengurutkan), mentransfer, membandingkan (Saleh, 2018).

Biasanya, prosedur pencatatan kas kecil digunakan sebagai alat untuk mencapai tujuan tertentu. Dalam pelaksanaannya, proses prosedur ini melibatkan pihak-pihak yang terlibat dalam pencatatan kas kecil, jenis pemrosesan, dan perintah kerja yang dilakukan dalam aktivitas yang dilakukan oleh PT BJS (Gambar 3.1). 


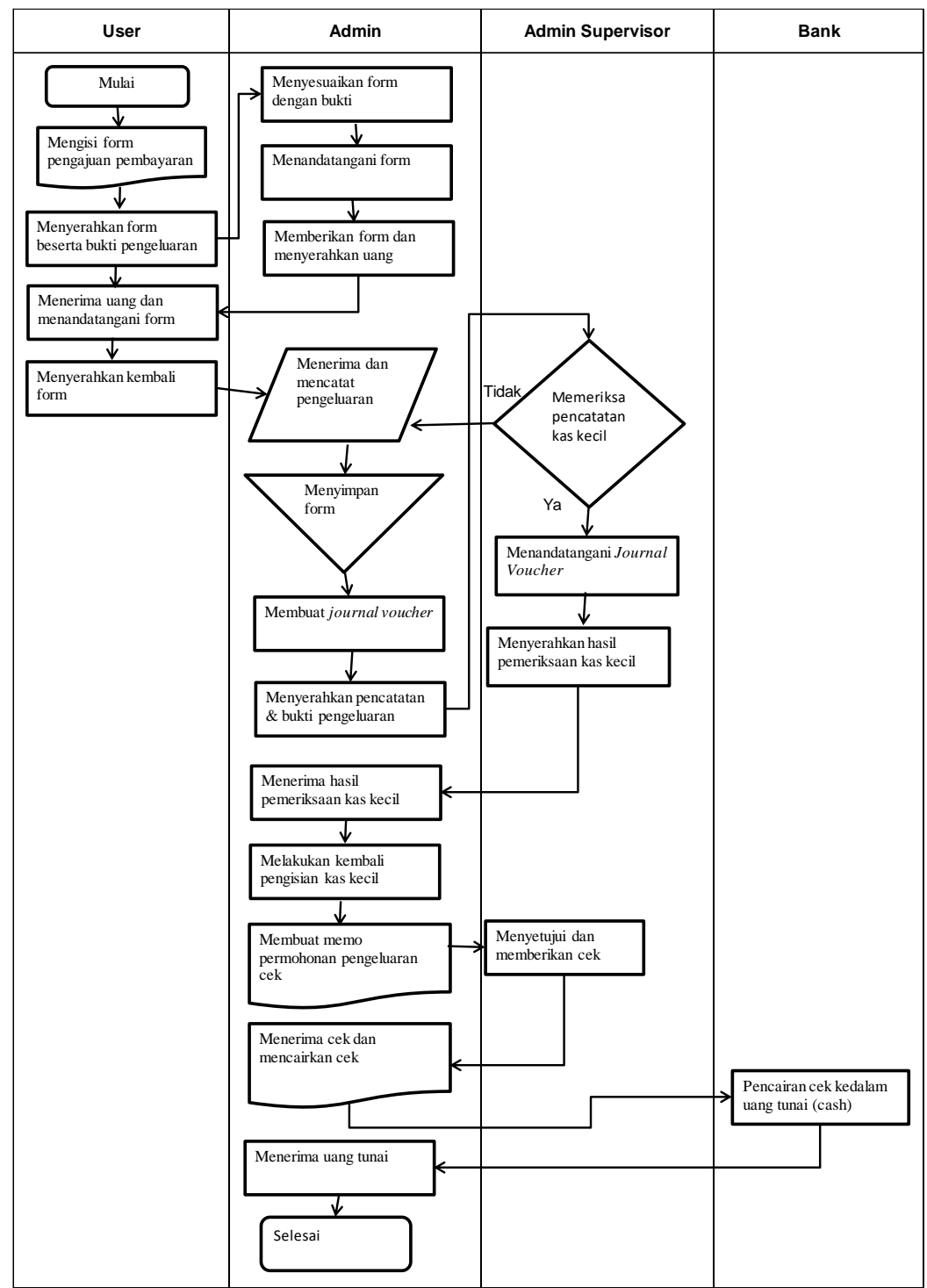

Gambar 1

Prosedur Pencatatan Kas Kecil

Sumber: Data yang diolah

Berdasarkan gambar di atas maka penulis menggambarkan proses pencatatan kas kecil di PT BJS sebagai berikut:

\section{User}

Hal pertama yang harus dilakukan dalam pengajuan dana kas kecil atau mengeluarkan sejumlah dana kas kecil dari admin adalah mengisi formulir pengajuan pembayaran terlebih dahulu (pembayaran dimuka). User mengisi formulir pengajuan pembayaran dan kemudian menyerahkan formulir pengajuan pembayaran kepada admin disertai dengan berbagai bukti pengeluaran kas kecil seperti faktur, kwitansi, bon dan lain-lain. Setelah pengeluaran disesuaikan, user akan menerima uang pengganti sebagaimana tercantum pada formulir pengajuan pembayaran dan kemudian menandatangani formulir pengajuan pembayaran di bagian "penerima" 
yang menunjukkan bahwa user telah menerima sejumlah uang pengganti kas kecil dari kasir kemudian formulir tersebut dikembalikan ke kasir (NikmahSajow, 2013).

\section{Admin}

Admin menerima formulir pengajuan pembayaran kas kecil dan beberapa bukti pengeluaran dari user, kemudian menyesuaikan apakah jumlah nominal yang tertera pada formulir pengajuan pembayaran sesuai dengan bukti yang dikeluarkan atau faktur terlampir. Jika formulir sudah sesuai dengan bukti yang dilampirkan, maka admin akan menandatangani formulir tersebut di kolom "admin", yang menunjukkan bahwa pengajuan sudah sesuai. Kemudian admin akan menyerahkan sejumlah uang kas kecil kepada user sesuai dengan yang tertera pada formulir pengajuan yang diserahkan kepada admin. Admin akan mencatat masing-masing transaksi pengeluaran di komputer, dengan mengisi periode, nomor bukti, nama pengeluaran dan nominal pembayaran, dan kemudian menyimpan bukti pengeluaran kas kecil ke dalam ringkasan kas kecil (Febrianti, 2021).

Sebelum pengisian kas kecil, admin akan memposting semua transaksi pengeluaran ke dalam journal voucher. Hal ini menunjukkan bahwa semua transaksi pengeluaran telah masuk ke dalam sistem perusahaan. Journal voucher akan diisi dengan tanggal, nomor bukti, dan informasi sesuai dengan transaksi pengeluaran yang telah dicatat sebelumnya. Kas kecil yang diposting dilampirkan dan ditandatangani oleh admin pada bagian "prepared by" dan "posted by". Semua biaya yang termasuk dalam ringkasan kas kecil kemudian akan diserahkan ke admin supervisor untuk diperiksa pencatatannya. Setelah disetujui, admin akan mengisi kas kecil. Untuk pengisian ulang, admin akan menulis memo permohonan pengeluaran cek ke admin supervisor. Admin kemudian akan menerima cek dan mencairkan cek tersebut di bank, dan akan menjadi saldo awal kas kas kecil pada periode berikutnya (Isnawati, 2021).

\section{Admin Supervisor}

Bagian admin supervisor menerima dan mengkonfirmasi semua bukti pencatatan kas kecil yang diserahkan oleh admin. Setelah disetujui, admin supervisor akan mendandatangani journal voucher pada bagian "reviewed by" dan menyerahkan kembali hasil pemeriksaan tersebut ke bagian admin. Untuk pengisian kembali kas kecil, admin supervisor akan menerima memo permohonan pengeluaran cek dari admin. Setelah disetujui, admin supervisor akan mengeluarkan cek dan memberikan cek tersebut kepada admin.

\section{Bank}

Bank menerima cek dari admin, yang kemudian cek tersebut diuangkan dan Bank menyerahkan uang tersebut kepada admin (Sajow, 2016).

\section{Kendala yang Dihadapi}

PT.Badar Jaya Sakti (BJS) adalah perusahaan yang bergerak di bidang Pengiriman Dokumen (Courier Service) maupun barang-barang (Good Service) yang dapat dikirim ke seluruh nusantara (domestik) melalui sistem cetak dan pelaporan online. Dalam kegiatannya, PT BJS biasanya melakukan transaksi kas kecil, namun 
tidak menerapkan Standar Operasional Prosedur (SOP) untuk pengelolaan kas kecil, sehingga sering terjadi kesalahan seperti kesalahan pembukuan kas, dan masih banyak metode yang tidak mengikuti standar operasional prosedur.

Prosedur transaksi keuangan kas kecil juga membantu menghindari penipuan yang mungkin dilakukan oleh pihak-pihak yang terlibat. Penggunaan prosedur operasi standar untuk semua transaksi kas kecil juga merupakan bentuk transparansi dalam penggunaan anggaran perusahaan. Dengan menerapkan prosedur operasi standar, pemegang kas dapat melaksanakan tugasnya dengan baik dan benar sehingga dapat mencapai tujuannya secara efektif dan efisien (Rusdianti, 2018).

\section{Cara Mengatasi Kendala}

Berdasarkan permasalahan yang terjadi pada PT BJS khususnya pada standar operasional prosedur Kas Kecil sering terjadi kesalahan berupa pencatatan yang tidak akurat pada buku kas dan terdapat beberapa metode yang tidak sesuai dengan standar operasional prosedur. Oleh karena itu, penulis memberikan solusi kepada PT BJS untuk dapat menerapkan standar operasional prosedur yang telah ditambahkan beberapa metode dan dipisahkan jenis kegiatannya berupa pengisian dan penerimaan dana kas kecil oleh penulis, solusi ini diharapkan kedepannya dapat meningkatkan kinerja pelayanan, kualitas laporan, dan memiliki petunjuk pelaksanaan pekerjaan sesuai dengan Standar Operasional Prosedur yang ditetapkan (Pratiwi \& Octavia, 2021).

\section{Pembelajaran Yang Diperoleh dari Kerja Profesi}

Pembelajaran yang diperoleh penulis selama melaksanakan Kerja Profesi Alternatif, penulis dapat belajar dan mendapatkan pengetahuan baru mengenai proses pengelolaan kas kecil PT BJS, Pondok Aren Tangerang Selatan. Penulis juga belajar tentang membangun hubungan dan berkomunikasi dengan baik dalam memperoleh informasi melalui wawancara dengan nara sumber. Bagaimana cara mengolah informasi yang diperoleh dari hasil wawancara, dan disajikan dalam bentuk laporan kerja profesi alternatif ini.

\section{Kesimpulan}

PT Badar Jaya Sakti (PT BJS) adalah perusahaan yang bergerak di bidang Pengiriman Dokumen (Courier Service) maupun barang-barang (Good Service) yang dapat dikirim ke seluruh nusantara (domestik) melalui sistem cetak dan pelaporan online.

Pengelolaan kas kecil yang diterapkan oleh PT BJS yaitu dengan menggunakan metode berubah-ubah (fluctuation system). PT BJS tidak menetapkan angka pasti untuk pengisian kembali dana kas kecil dalam satu periode pengeluaran. Dana kas kecil tersebut digunakan untuk membiayai kegiatan-kegiatan operasional perusahaan yang jumlahnya relatif kecil dan bersifat rutin.

Berdasarkan permasalahan yang terjadi pada PT BJS khususnya pada standar operasional prosedur kas kecil sering terjadi kesalahan berupa pencatatan yang tidak akurat pada buku kas dan terdapat beberapa metode yang tidak sesuai dengan standar 
operasional prosedur. Prosedur transaksi keuangan kas kecil, membantu menghindari penipuan yang mungkin dilakukan oleh pihak-pihak yang terlibat.

\section{BIBLIOGRAFI}

Akbar, S. H. E., Ma'ani, Bahrul, \& Irsyadunnas, Irsyadunnas. (2019). Eksistensi Industri Kecil Lacak Di Mendalo Dalam Upaya Peningkatan Kualitas Ekonomi Masyarakat Di Tinjau Dari Perspektif Hukum Ekonomi Syariah. Uin Sulthan Thaha Saifuddin.Google Scholar

Aslichati, Lilik, Tutisiana, M., Suryanto, Adi, \& Andriyansah, M. M. (2020). Seminar Nasional Pengabdian Kepada Masyarakat 2018 (Senmaster 2018). Google Scholar

Elfin, Elfin. (2021). Menginput Kartu Persediaan Barang Pada Bidang Keuangan Dan Perlengkapan Dinas Perhubungan Kabupaten Bengkalis. Google Scholar

Febrianti, Murni. (2021). Analisis Pelaksanaan Pencatatan Petty Cash (Kas Kecil) Pada Pt Advantage Tegal. Politeknik Harapan Bersama Tegal. Google Scholar

Fitriani, Melati Indah Nur. (2021). Analisis Pengelolaan Dana Kas Kecil Pada Kerjasama Ppa Nindya Tegal (Perumahan Green Teksin Tegal). Politeknik Harapan Bersama Tegal. Google Scholar

Isnawati, Muslihah. (2021). Rancang Bangun Akuntansi Keuangan Sekolah Dengan Client Server Method (Study Kasus Sma Muhammadiyah 2 Bandar Lampung). Jurnal Portal Data, 1(2). Google Scholar

Nariswari, Risti, \& Subkhan, Muhammad. (2018). Analisis Efektifitas Sistem Pengendalian Intern Kas (Studi Kasus Pada R\&B Grill Restaurant). STIE Widya Wiwaha. Google Scholar

Nikmah, Masriatun. (2013). Penerapan sistem informatika akuntansi pada Klinik Daqu Sehat Malang. Universitas Islam Negeri Maulana Malik Ibrahim. Google Scholar

Pratiwi, Utari Nur, \& Octavia, Evi. (2021). Tinjauan Prosedur Akuntansi Pengeluaran Kas Atas Pengajuan Dan Pembayaran Klaim Jaminan Hari Tua Pada Bpjs Ketenagakerjaan Kcp Bandung Barat. Jurnal Akuntansi Bisnis Dan Ekonomi, 7(1), 1881-1900. Google Scholar

Rusdianti, Imanita Septian. (2018). Pengaruh Pengendalian Internal, Ketaatan Aturan Akuntansi Dan Perilaku Tidak Etis Terhadap Kecenderungan Kecurangan Akuntansi Pada Pt. Ciomas Adisatwa, Tbk Region Jatim 1 Malang. Google Scholar

Sajow, Chredo Wiko. (2016). Tinjauan Yuridis Tentang Cek Dalam Sistem Pembayaran. Lex Crimen, 5(5). Google Scholar 
Saleh, Ahmad. (2018). Evaluasi Pengelolaan Petty Cash Pada PT.PLN (Persero) UPB Sulselrabar. 151(2), 10-17.

Siregar, Veliana. (2020). Laporan Magang Kerja PT Bank Rakyat Indonesia (Persero) Tbk Kantor Cabang Bandar Jaya. STIE YKPN. Google Scholar

Wati, Embun Fajar, \& Kusumo, Arvin Anggoro. (2016). Penerapan Metode Unified Modeling Language ( UML ). UNSIKA Syntax Jyrnal Informatika, 5(1), 24-36. Google Scholar

\section{Copyright holder:}

Nurwinda Safitri (2021)

First publication right:

Syntax Idea

This article is licensed under:

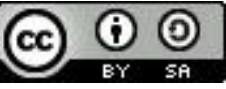

